\title{
Reflections on globalization processes in geopolitical thought since the second half of the 20 th century
}

\author{
Robert Ištok $^{1}$, and Irina Kozárová2, ${ }^{2 *}$ \\ ${ }^{1}$ University of Prešov in Prešov, Faculty of Humanities and Natural Sciences, 17. novembra 1, 08001 \\ Prešov, Slovakia \\ ${ }^{2}$ University of Prešov in Prešov, Faculty of Management, Konštnatínova 16, 08001 Prešov, Slovakia
}

\begin{abstract}
Research background: Geopolitical thought at the turn of the $19^{\text {th }}$ and $20^{\text {th }}$ centuries was among the first to accentuate a global dimension of international politics. It stagnated in the context of WWII, however, the adoption of geopolitical approaches in U.S. foreign policy concepts contributed to its revival during the Cold War and its rapid development in the 1990s because of the need to address the changes in the power-political and spatial-political structures of the world. The relationship between geopolitical thought and globalization, however, remains controversial. In academic literature, geopolitics and globalization are perceived either as compatible or as incompatible phenomena.

Purpose of the article: The paper aims to outline how geopolitical thought has reflected the development of globalization processes and how it has changed with this development since the $2^{\text {nd }}$ half of the $20^{\text {th }}$ century.

Methods: Analytical-synthetic and historical-comparative methods are used for the study of globalization development and content analysis and comparative methods are employed to map the development of geopolitical thought and its reflection of globalization.

Findings \& Value added: The development, direction and consequences of globalization have been reflected in geopolitical thought mainly since the 1990s. As a result, new trends in geopolitical thought have been established; apart from the changes in the power-spatial and political-spatial structures of the world studied by classical geopolitical thought, they also reflect the relationship between global and local, an acceleration in contradictory processes in the world caused by economic, cultural, demographic, information and other factors of spatial control.
\end{abstract}

Keywords: international relations; international politics; globalization; geopolitical thinking

JEL Classification: F50; F59; N40

\footnotetext{
*Corresponding author: irina.kozarova@unipo.sk
} 


\section{Introduction}

The relationship between geopolitical thought and globalization processes has currently become a subject of many academic debates. The first line of discussion raises a question whether geopolitics and globalization are compatible phenomena (Baylis et al., 2020). Some authors ask whether globalization would lead to "the end of geopolitics", the others wonder about "the end of globalization" in terms of the efforts of states to regain their sovereignty (Mihaylov and Sitek, 2021). In this regard, Bielen (2009) states that many authors overestimate the significance of globalization and geopolitics and that both of the phenomena are interdependent and complementary.

The second line of discussion focuses on the question whether the world of the future will be based on "traditional power dynamics with untraditional players" or whether "new" geopolitical thought based on other principles than the use of traditional hard military power will prevail (Baylis et al., 2020, p. 248). In this regard, Falk (2015) characterizes the current period as transitional; "old" geopolitics has not disappeared yet but can no longer be able to transform its preferences into desired results, while "new" geopolitics is in its infancy and it cannot resist "old" geopolitics and shape international affairs.

\section{Methods}

The aim of the contribution is to outline how geopolitical thought has reflected the development of globalization processes and how it has changed with the development of globalization since the $2^{\text {nd }}$ half of the $20^{\text {th }}$ century. To fulfil the aim, the analytical-synthetic and historical-comparative methods were used for the study of the development of globalization processes and the methods of content analysis and comparison were employed to map the development of geopolitical thought and its reflection of globalization.

\section{Results and Discussion}

\subsection{The development of globalization processes since the $2^{\text {nd }}$ half of the $20^{\text {th }}$ century}

Within the fields of social sciences, there is still no common understanding of globalization. Globalization is characterized as the spread of phenomena across the entire world, a social process or trend, or as a set of processes or trends, a specific configuration of global power, a strategy, or an ideology (see Kozárová, 2017). In our research, globalization is characterised as "a social process manifesting itself in the process of social being (economics, technology, etc.) and social consciousness (ideology, politics, law, ethics, culture, etc.) as an intensification of social relations on the local, regional, continental, intercontinental, or global scale, which is followed by an increase in the interconnectedness and interdependence of human society; a historical process which remains an uncompleted process at the present time and whose quality and quantity have been changing over the course of its development; a controllable process; the potential for its control increases with the development of human understanding of the process (a spontaneous process in the past, a controlled process, or there is a tendency to control it, in some fields of social life while it is a spontaneous, uncontrolled process in the other fields of social life at the present); [a process] contradictory in character, a quality which manifests itself through the attainment of different levels of intensity and acceleration in various territories and in various social spheres, or through the different impacts and results which emerge despite it works on uniform principles; [a process] whose level of intensity and differences in impacts [...] are determined by the driving forces of 
globalization, socio-historical development, socio-economic relations, and the natural environment (Kozárová, 2017, p. 66).

The increase in number and importance of international organizations was specific to the development of globalization after the Second World War; it was the result of the need to solve various global problems at supranational level. The greater coordination of social relations, however, was not established at global level but only within two politically and ideologically distinct blocs, the growing tension between which evolved into the Cold War. The rivalry between the superpowers was very intensive at technological, especially military, and ideological level and escalated into the Caribbean crisis in the 1960s, which took the world to the brink of nuclear war. This experience eventually led the superpowers to seek cooperation on issues of mutual arms control and the competition gradually moved to the economic level; more intensive cooperation on environmental issues was also established.

In Western countries the direction of globalization of the 1970s was affected by the weakening of economic growth due to oil crisis and the collapse of the Bretton Woods system. The economically developed countries responded to the situation, inter alia, by convening informal groupings of countries (G5, G6, later G7) in an effort to coordinate their economic policies. In the United Kingdom and the United States, and later in the former British colonies, Latin America and Western Europe, the policies of free market, minimal government involvement in the economy, firm control over public expenditure and the development of new economic culture were adopted. The economies of the Soviet bloc countries could not compete with high capital accumulation and overproduction in Western countries and after its unsuccessful reform the Soviet Union was dissolved.

The globalization of the 1990s was particularly manifested in the strengthening of the hegemonic position of the United States within the global political system, the spread of neoliberal ideas and the adoption of neoliberal principles and measures at the global level. Trade liberalization, the deregulation of price and financial market, the liberalization of capital flows and the development of telecommunications created the conditions for the rise of multinational and transnational corporations, the emergence of new international divisions of labour and a virtual economy, and thus the growth of economic interdependence among countries. This form of globalization, however, did not bring benefits to all its players and it also made no allowance for the depletion of natural resources. For those reasons it became a subject of criticism which manifested itself by the emergence of anti-globalization (or alterglobalization) protests and the establishment of regional organizations based on alternative (non-liberal) principles (Kozárová, 2017).

The development of globalization in this direction was hindered by the 2007/2008 global financial crisis and its aftermath, due to which the contradictions within globalization have been exacerbated. On the one hand, globalization has manifested itself by the creation of informal groupings of leading countries (G20, BRICS) and the signing of international agreements (Basel III, the Paris agreement, etc.) in the efforts to solve global problems (Kozárová, 2018), however, this development has been accompanied by the existence of "no consensus on the right economic framework [... and] no agreementon what the appropriate rules for governing globalization should be" (Stiglitz, 2021, p. 795). At the same time there has occurred the weakening of the hegemonic position of the United States, increased competition for technological, military, or economic supremacy between the United States and Russia/China, the expansion of intergovernmental military or security alliances (NATO, Shanghai Cooperation Organisation - SCO), the establishment of alternative financial institutions (the New Development Bank established by BRICS, etc.), trade wars (Kozárová, 2018), the rise of populism (Rodrick, 2021) and nationalism (Flew, 2020). 


\subsection{Reflections on globalization processes in geopolitical thought since the second half of the 20th century}

Geopolitics suffers from a number of problematic aspects, the foremost of which is the still unresolved issue of its categorisation within the system of the social sciences. In academic literature, geopolitics is variously characterised as the applied sphere of several disciplines, a theory, a concept, a methodology, a strategy, a doctrine or set of doctrines, or a method of thinking, but also as a science. A further shortcoming of geopolitics is the lack of a universally accepted definition for the term, with an overview of the relevant literature revealing a wide range of differing interpretations. For this reason, we have attempted to construct as objective a definition of geopolitics as possible: "an applied multidisciplinary field of study which uses the findings of several academic disciplines (especially geography and political science) in the analysis of the behaviour of political subjects in a spatial context, with these analyses being integrated into the development of concepts, models and doctrines" (Ištok, 2004). In consequence of the development of new branches of geopolitical thought since the end of the $20^{\text {th }}$ century which will be discussed below, it is possible to speak in this context of classical (or traditional) geopolitics.

In terms of the context of this contribution, it is possible to state that the global dimension of analyses of geopolitical thought was already apparent in the period in which the field of study emerged in the late $19^{\text {th }}$ and early $20^{\text {th }}$ centuries. This trend in the formation of geopolitical analytical concepts was not only the result of advances in knowledge but also a reaction to accelerating processes of globalization which were reflected in, among others, the cementing of the division of land between states. As M. Kupka has noted, "by the beginning of the $20^{\text {th }}$ century, the world appeared to be a closed system where it was no longer possible for a state to wage war for geographical space without encroaching upon the interests of other states" (Kupka 2001). Many authors have emphasised that it was in fact classical geopolitics which focused on the global dimension of international politics in this period.

The work of the British geographer H. J. Mackinder was pioneering in this respect, more specifically his geopolitical theory of the Heartland which he developed between 1904 and 1943. The French geopolitical thinker G. Dussouy has stated that "Mackinder represents a true forerunner to the global approach in international relations from a planetary perspective" (Dussouy, 2001). This also corresponds to the characterisation of Mackinder's theory by the British historian G. Parker (1998) who argues that his work can be categorised as "geopolitical scenarios on a global scale". In the years following the Second World War, other authors from the Anglo-Saxon sphere elaborated further on Mackinder's theories, developing the approach in a more or less critical manner (J. Burnham, R. Strausz-Hupé, D. W. Maining and others). An unambiguously critical view of Mackinder's theory was taken by N. J. Spykman in particular, with many thinkers in international relations responding to this thesis in the early years of the Cold War. A common feature of the work of all of the above-mentioned authors was their use of a global geopolitical approach.

These works are currently considered as part of the classical geopolitical thought which developed after the Second World War primarily in opposition to the concept of "geopolitics", a result of the discrediting of the trend in spatial-political analysis formulated by the interwar school of German geopolitical thinkers known as geopolitik. Nonetheless, several international political decisions taken in the Cold War period emerged were based on geopolitical starting points, even though the term itself was seldom used. H. Kissinger, who served in the administrations of the U.S. Presidents R. Nixon and G. Ford from 1969 to 1977 contributed greatly to the "legitimization" of the term of geopolitics through his conception of international politics. Kissinger returned the concept of geopolitics to the lexicon of international relations and the term has since become established across the mass media. 
Generally considered to be the most significant proponent of (neo)classical geopolitical thought of the Cold War period, the American geographer S. B. Cohen first presented his concept of geopolitics in his book Geography and Politics in a World Divided which was published in 1963. Cohen updated his theory in response to global developments in a further three works, the last of which was published in 2008 under the title Geopolitics. The Geography of International Relations. Cohen's first work presented the division of the world into two categories of zones - geostrategic regions and the inferior geopolitical regions. Geostrategic regions (later referred to as geostrategic spheres of influence or realms) reflected the bipolarity of the Cold War period and the dominance of the two superpowers of the United States and the Soviet Union, but he also noted the emergence of a third geostrategic realm in South Asia. Within this framework he also defined areas which he termed shatterbelts, zones of instability in which conflicts between the superpowers of the geostrategic realms could play out (primarily the Middle East and Southeast Asia, but later publications also included Sub Saharan Africa among this list).

In his other works, Cohen set out to account for developments in global politics. He formulated a set of criteria for evaluating state power and applied this theory to form five categories of countries. Among the highest level he categorised powers with a global reach (the United States, integrated Europe, Japan, Russia and, potentially, India). The next category was represented by regional centres of power (Iran, Indonesia, Mexico, Brazil, Australia and others), states which were dominant within "their" respective regions. Cohen also responded to the end of the Cold War and the developments of the early $21^{\text {st }}$ century, theorising the spatial-political category of gateways, transitional states and regions which play a role in connecting various parts of the world through the exchange of people, goods and ideas (for example, Austria, Slovenia and Estonia). Cohen's theory of geopolitics also included other spatial-political concepts through which he responded to developments within an unstable world (see Cohen, 2008).

The end of the Cold War led to a sharp increase in the number of publications dedicated to geopolitics. This increased interest was not only related to the changes in political-power structures at the international level but was also a result of the growing number of subjects in international relations (such as states, international organisations, ethnic groups and separatist movements). The growth was also associated with the pressure to secure and control natural resources and later with the consequences of climate change. Also of significance in this respect was the renaissance of geopolitics related to the emergence of new trends associated with the processes of globalisation including the fragmentation of power at the state level in favour of non-state actors. Geopolitical studies have responded to the emergence of these trends by widening the focus of its analyses.

It can be argued that current global trends have validated the flexibility of geopolitical thought and the field of study has also shown itself to be capable of self-reflexion, a factor which has resulted in the emergence of new branches of geopolitical thought, the most active of which is critical geopolitics. This novel trend was first developed by the American political scientist G. Ó Tuathail in the late 1980s, later joined by other thinkers including, among others, S. Dalby, K. Dodds and J. Agnew. The emergence of critical geopolitical thought is linked with a number of trends such as the processes of globalisation which have been intensified by the technological revolution and the wave of democratisation which followed the end of the Cold War.

The concept of critical geopolitics is based on the premise that there is no single concept of "geopolitics", but that the field is rather a conglomeration of several ideas and images which manifest themselves within a society. Critical geopolitics rejects the deterministic geographical framework which was predominant in classical geopolitics, where space was seen as a fixed constant, subject to regular patterns. As G. Ó Tuathail writes, critical 
geopolitics is "an analysis of how geopolitical configurations and assumptions concerning the world are transformed into political projects and the associated geographical images that condition the collective imagination, generating a specific image of the world" (Ó Tuathail, 1994).

Within the context of historical development, however, it must be emphasised that politics is closely connected to the full scope of human activities, and to the field of economics in particular. Geopolitics, which until recently was focused on the control of geographical space by states through political power, especially that of military force, is now also required to take into economic factors into account, an aspect which exerts an increasing influence on the power-based control of geographical space. This context has led to the emergence of a novel geoeconomic approach to geopolitics. Current trends are also bringing about a transition in classical geopolitical thought, moving away from a static understanding of space towards a deeper consideration of the impact of dynamizing factors including those related to the economy.

Therefore, even "classical" geopolitical thought can be conceived in a far wider sense than has been the case over the last three decades, and the field of study has acquired more complex and dynamic starting points and conclusions which correspond more closely to the demands of the globalized world. The emergence of new terminology which indicates the distinct orientations of geopolitical thought is connected with the growing significance of economic, cultural, demographic and other predominantly sociological factors in the development of spatial power relationships (Buček, 1995). These considerations can give rise to such concepts as geoeconomics (see e.g. Moisio, 2019), geoculture (see e.g. Kazancev, 2008) and geodemographics (see e.g. Fedorov, 2014) but also geostrategy (see Brzezinski, 1997) and geohistory (see e.g. Grataloup, 2004), although there is often some ambiguity over the precise meaning of these terms. Many authors have also noted that spatial conflicts will increasingly be played out in the informatic sphere and thus we will see the growing importance of a new direction of thought - geoinformatics (Sinha, 2006).

\section{Conclusion}

It is apparent that the fulfilment of the emancipation of geopolitics and the emergence of new directions of study within its framework have refuted the predictions of "the end of geography" and of the demise of spatial-oriented ways of thinking. Proponents of this thesis predicted the emergence of a world without borders in which geographical space would lose its political significance. In reality, globalization has given rise to a fragmented world which is marked by deep inequality, and it is imperative that its development and consequences be analysed in detail. The processes of globalization do not necessarily represent a refutation of geopolitics; indeed, the very opposite is the case. They serve as a new stimulus for the development of geopolitical thought which can lead to novel and surprising conclusions.

\section{Acknowledgements}

This work was carried out as part of the research project titled "Dysfunctional States - The Current Phenomenon of a World Political-Space Structure" supported by the Scientific Grant Agency of the Ministry of Education, Science, Research and Sport of the Slovak Republic and Slovak Academy of Sciences (Vedecká Grantová Agentúra MŠVVaŠ SR a SAV VEGA) under grant no. 1/0544/21, led by Prof. RNDr. Robert Ištok, PhD. 


\section{References}

1. Baylis, J., Smith, S., \& Owens, P. (2020). The globalization of world politics (8th ed.). Oxford University Press.

2. Bieleń, S. (2009). Geopolityczne myślenie o łaczie międzynarodowym. Przegląd geopolityczny, 1, 27-46.

3. Brzezinski, Z. (1997). A geostrategy of Euroasia. Foreign Affairs, 76(5), 50-64.

4. Buček, J. (1995). Geopolitika na konci 20. storočia. Medzinárodné otázky, 4(3), 41-53.

5. Cohen, S. B. (2008). Geopolitics: The Geography of International Relations. Rowan \& Littelfield.

6. Dussoy, G. (2001). Quelle géopolitique au XXIe siècle. Éditions Complexe.

7. Falk, R. (2015). Humanitarian Intervention and Legitimacy Wars. Routledge.

8. Fedorov, G. (2014). Current Issues in the Geodemographic studies in Russia. Baltic region, 2, 4-21

9. Flew, T. (2020). Globalization, neo-globalization and post-globalization: The challenge of populism and the return of the national. Global media and communication, 16(1), 1939.

10. Grataloup, C. (2004). Fernand Braudel - and afterwards? A second impetus for geohistory. Geographische Zeitschrift, 92(3), 147-154.

11. Ištok, R. (2003). Politická geografia a geopolitika. Fakulta humanitných a prírodných vied PU.

12. Kazancev, A. (2008). Political globalization studies: A conflict of interpretation and ways to overcome it. Politeia-Journal of political theory, political philosophy and sociology of politics, 49(2), 126-141.

13. Kozárová, I. (2017). Hybné sily globalizácie. Prešovská univerzita v Prešove.

14. Kozárová, I. (2018). Outline of the development of the driving forces of globalization in the first two decades of the 21st century. In Frankovský, M., Dobrovič, J., Fedorko, R. (Eds.), Management 2018: management and the world in motion, challenges, opportunities and threats (pp. 675-679). Bookman.

15. Kupka, M. (2001). Moderní geopolitické teorie v USA. Mezinárodní vztahy, 36(2), 8397.

16. Mihaylov, V., \& Sitek, S. (2021). Trade wars. Miscellanea geographica, 25(2), 99-109.

17. Moisio, S. (2019) Re-thinking geoeconomics: Towards a political geography of economic geographies. Geography Compass, 13(10), 1-13.

18. Ó Tuathail, G. (1994). The critical reading/writing of geopolitics: reading/writing Wittfogel, Bowman and Lacoste. Progress in Human Geography, 18(3), 315-329.

19. Parker, G. (1998). Geopolitics: Past, Present and Future. Pinter Pub.

20. Potulski, J. (2021). Od geografii „radykalnej“ do geopolityki „krytycznej“. In Kloczkowski, J. (Ed.), Geopolityka. Stowniki społeczne (pp. 41-58). Wydawnictwo Naukowe Akademii Ignatium.

21. Rodrik, D. (2021) Why Does Globalization Fuel Populism? Economics, Culture, and the Rise of Right-Wing Populism. Annual Review of Economics, 13, 133-170.

22. Sinha, A. K. (2006). Geoinformatics: Data to Knowledge. Geological Society of America.

23. Stiglitz, J. (2021). Globalization in the aftermath of the pandemic and Trump. Journal of Policy Modeling, 43 (4), 794-804. 